Ливија Д. ЕКМЕЧИЋ

Универзитет у Стразбуру

Филолошки факултет
Оригинални научни рад

Примљен: 13. 01. 2020.

Прихваћен: 12. 02. 2020.

\title{
СЛИКА ФРАНЦУСКЕ У ТРАВНИЧКОЈ ХРОНИЦИ
}

\begin{abstract}
У овом раду настојали смо да осветлимо слику Француске у роману „Травничка хроника", као и да сагледамо ликове Француза и њихове међусобне односе. Показано је да се слика Француске конституише на две равни. Прву раван чини слика Француске као државе, која је у роману грађена и непосредним приказима и посредним, кроз сочиво неког од јунака, док другу раван представљају сами протагонисти - Французи. Такође, осветљен је основни принцип посредством којег Андрић ствара слику француског света у роману „Травничка хроника”, а то је принцип опозиције, односно контраста.

Кључне речи: Француска, ликови Француза, односи међу протагонистима, јавно и приватно биће јунака, опозиција, контраст.
\end{abstract}

Роман „Травничка хроника” представља праву малу енциклопедију ликова у којој се јављају најразличитији протагонисти са различитим улогама у радњи романа, од епизодних улога до главне улоге у којој се појављује француски конзул. Поред богате палете ликова у овом Андрићевом роману јасно се могу разазнати и слике два света. Један свет представља Босна, а кроз њу Исток, док други свет представља Запад приказан кроз Наполеонову Француску и делимично кроз Аустрију. У оквиру ове прве приказани су и различити светови различитих верских групација: православци, католици, Јевреји и муслимани.

Слике два света формирају се на различите начине, посредством њихових представника, односно, кроз јунаке који припадају тим световима, али на одређен начин и кроз јунаке који не припадају тим световима, кроз непосредне и посредне слике Босне, Травника, Француске итд. На обликовање слике света у роману „Травничка хроника” утиче и начин приповедања који Андрић употребљава. Како би постигао живу и динамичну слику, писац комбинује панорамско и миметичко приповедање (в. Штанцл 1987: 23-26). Такавим поступком истовремено се остварује уверљивост приказане слике

*livijaekmecic@yahoo.com 
света и динамичност романескних ситуација. Комбинујући две врсте приповедања, Андрић слике из историје (в. Шамић 2005) везане за различите светове (и Босну и Француску, али и Аустрију) приказује на један непосредан начин у коме читалац стиче утисак да и сам присуствује догађајима о којима је реч.

Француски свет у роману „Травничка хроника” приказан је кроз ликове Француза и кроз слику саме Француске као државе, која до читаоца допире на неколико начина. Ти начини су непосредни приказ Француске кроз слике, као што је она у којој се приказује формирање Министарства спољних послова, или кроз нараторов коментар о Француској, и посредни, где је слика Француске преломљена кроз сочиво различитих протагониста.

Основни принцип који се појављује у грађењу слике француског света у „Травничкој хроници” је принцип опозиције. Овај принцип је најпре остварен у самој романескној ситуацији у којој се француски, односно Западни свет приказује у оквирима Босне, која је у време радње романа део Отоманске империје, дакле, у оквирима Источног света. Потом се исти принцип јавља на плану ликова, који су на различите начине постављени један наспрам другог. Принцип опозиције је првенствено остварен у додиру мештана и Француза, потом у додиру два конзула (француског и аустријског), али је најизраженији у сусрету две генерације Француза, чији су представници Давил и Дефосе. На крају, како је у својој студији „Јавни и приватни светови у 'Травничкој хроници'" запазио Ален Фергусон, та опозиција јавља се и у оквиру једног лика, а реч је о опозицији приватног и јавног живота појединих протагониста.

Следећи доследно принцип опозиције у грађењу слике француског света у роману „Травничка хроника”, писац нам на један особен начин приказује сасвим употпуњену, богату слику овог дела западног света. Та слика је између осталог богата и због начина на који Андрић позиционира ликове једне наспрам других, и даље следећи принцип опозиције. Тако у оквиру самих Француза имамо неколико веома значајних релација изграђених на овом доминантном принципу. Једну чине Давил и његова жена, другу Давил и Дефосе, док се трећа налази у домену опозиције приватног и јавног бића код Давила, али у грубим цртама и код Дефосеа. (Усаглашавајући друге представнике Француске са ликом конзула, али и све остале протагонисте романа, Андрић поставља лик Давила као централну фигуру свог романа.)

Приликом увођења ликова у роман писац даје основне оквире кретања лика о коме је реч. На тај начин он посредно, а некада и непосредно, сугерише позицију лика у односу на главног јунака романа, односно у односу на Давила. Таква је ситуација и са увођењем госпође Давил, међутим, опозиција коју она заузима наспрам свога супруга слика се посредним путем. Уводећи је у роман, приповедач нам пружа две кључне информације говорећи да је она: „Једна од оних жена за које у нас кажу 'да им се ништа није отело'. Њен живот, то је била фантастична али разборита и стрпљива служба кући и својима. Тој служби су биле посвећене њене мисли и њена осећања, а њене танке, увек црвене и наизглед слабачке руке, које нису никад мировале, савлађивеле су посао као да су од челика. Из добре грађанске породице, која 
је једним случајем пропала за време револуције, она је одрасла код ујака, бискупа од Авранша, и била је искрено побожна оном нарочитом француском чврстом а човечном побожношћу, без колебања али и без биготизма" (Андрић 1996: 53). У првом делу непосредно је наговештена јунакиња, која је носилац традиционалних вредности и која је оличење традиционалне жене, док је у другом делу описа укратко, али за разумевање њене позиције врло значајно, наговештено њено порекло. Овако уведена у роман она постаје својеврсна противтежа своме супругу. Док је он окренут спољашњем као представник буржоазије, дотле је она окренута унутрашњем животу. И док се кроз његов лик преламају типичне ситуације француске буржоазије, што се нашла између легитимног краља и Наполеона, дотле за госпођу Давил спољашњи фактори немају никакав утицај, чак ни и у ситуацији у којој су они имали врло неповољан одраз на породицу из које она потиче.

Лик госпође Давил, управо кроз традиционалне вредности, премошћава раздаљину између два света, између Истока и Запада, за које се понекад верује да се не могу међусобно разумети. Госпођа Давил, која долази из Западног света, постаје узорна жена на Истоку. Због тога она, како је то у литератури већ на више места запажено, постиже оно што конзул ни на један од својих дипломатских или мање дипломатских начина не може да постигне. Односно, она успева да успостави везу са мештанима, и муслиманима и католицима, па чак и са „тврдим” фратрима који, како то Андрић описује, не воле цара неверника нити његовог представника.

За разлику од госпође Давил, чија је позиција у односу на конзула приказана посредним путем, позиција младог канцелара, Дефосеа сугерисана је врло експлицитно. „Давил је био човек који се приближавао четрдесетим годинама а Дефосе је ушао у двадесет и четврту. Та разлика у годинама не би била велика ствар у другим временима и друкчијим приликама. Али бурна времена, са великим променама и социјалним поремећајима, ископају и продубе непремостив јаз између два нараштаја и створе од њих стварно два света" (Андрић 1996: 57). После оваквог увода, сасвим природно следио је низ ситуација у којима су Давил и Дефосе приказивани заиста као два света. Њихова мимоилажења налазе се на различитим нивоима, али основни је садржан у различитом односу према јавном животу. Појмове Краљевство, Револуција и Наполеон Давил уме једино да гледа кроз комплексан сплет сукоба, заноса и колебања, док Дефосе има само једно становиште маркирано практицизмом ${ }^{1}$. За њега су ови појмови сведени на: бајку, мутно сећање из детиғства и каријеру, где Царство поред каријере представља и „поприште неограничених могућности, акције, подвига и славе” (Андрић 1996: 64). Пишући о роману „Травничка хроника” Иве Андрића и Фергусон је указао на ову разлику између двојице представника Француза. „Ту је, дакле, још један сукоб унутар романа, између, како Андрић каже, 'два различита света Давила и Дефосеа' . Дефосеовог света новог нараштаја, који је одабрао да 'живи жи-

\footnotetext{
${ }^{1}$ Дефосеово становиште дато је и непосредно у његовом дијалогу са фра Јулијаном: „Важно је колико човек има од живота и шта у животу начини од себе, од своје средине и свога потомства" (Андрић 1996: 245).
} 
вот' и није заинтересован за 'Давилов свет идеја' и Давилов свет романтизма и идеализма" (Фергусон 1978: 859).

Опозиција између ова два лика јавља се и на нивоу њихових система вредности, што је приказано кроз однос који они имају према поезији. Док је за Давила поезија нешто узвишено, и једино што је, поред јавног живота, достојно поштовања, дотле за Дефосеа поезија нема никакву улогу. Он врло отворено, чак не водећи рачуна о томе како ће његов коментар примити Давил, каже да не мари за стихове, а да му француска савремена поезија изгледа неразумљиво. И управо у овом домену одраз њихових приватних бића може бити сагледан у њиховом стваралачком раду. Док Давил тајно пише еп о Александру Великом, који се претвара у његов интимни дневник, дотле Дефосе пише књигу о Босни, у којој се налазе конкретни описи и реалистичне ситуације.

Опозиција која је веома видљива код Давила и Дефосеа, честа је, када је реч о Дефосеу и позиционирању других ликова у односу на њега. Она није увек овако јасно изражена и није увек потпуна, али се код готово сваког лика који долази у додир са Давилом, она може приметити на известан начин. То потврђује и Фергусоново запажање о званичним представницима различитих држава. „Очигледно је да постоји не само сукоб између јавних супротних светова него да исто тако постоји сукоб између јавне слике и индивидуалног света двојице конзула. Андрић исцрпно показује како сукоб у јавном свету спречава реализовање сличности које постоје у приватном свету" (Фергусон 1978: 857). Овај сукоб између приватног и јавног мотивисаће још једну опозицију, када је реч о ликовима Француза. Та опозиција је између приватног и јавног бића код појединих ликова.

Наиме, опозиција која се јавља у оквиру једног протагонисте, а коју чине приватно и јавно биће, видљива је и код Давила и код Дефосеа. Иако код овог другог мање изражена, она је ипак присутна. Наиме, када је реч о Давилу нараторовим коментаром се јасно каже да Давилово јавно биће спутава Давилово приватно биће. Као пример те ситуације може послужити ситуација у којој се Давил нашао једном приликом када је био заједно са аустријским конзулом позван код везира, а поводом тога што су Турци брутално угушили покушај српског устанка. Том приликом Давила је затекао један варварски призор у коме су Турци конзуле најпре почастили лимунадом, а онда им показали ратни трофеј: „На асуру почеше да сипају одсечене људске уши и носеве у знатној множини, неописиву масу убогог људског меса, усољену и поцрнелу од усирене крви. [...] Давил, који ни у сну није могао очекивати овакав призор, осети како му се подиже стомак и лимунада горча у устима и прети да удари на нос" (Андрић 1996: 194). Међутим, уместо природне реакције коју почиње да испољава приватно биће, Давил исказује реакцију каква се очекује од њега као званичног представника Француске, односно, Давил на сцену пушта своје јавно биће. „Ревност и брига да не изостане за својим супарником савладаше и у Давилу страх и гађење и он изговори неколико реченица у част победе, са жељом за даљи успех царског оружја и мир у Царевини" (Андрић 1996: 194). Романескна ситуација коју смо издвојили 
представља илустрацију односа Давиловог приватног и јавног бића која је готово доследно спроведена кроз цео роман. Овде ваља нагласити да та разлика потиче из тога што је конзулово приватно биће дубоко обележено Давиловом романтичарском природом, док његово јавно биће увек остаје у веома прецизним оквирима деловања и понашања једног дипломате, односно јавног Наполеоновог представника.

Један други пример такође потврђује примат јавног у Давиловом лику, а то је тренутак у коме Давил сазна да је и други паша, с којим је он успео да изгради добре односе, смењен. Он најпре реагује као конзул: „И сад му је ова вест падала тешко и значила, у овим временима, неоцењив губитак. Али он није налазио више у себи снаге да се буни и опире", а потом као приватно биће: „Тек у другом реду Давилу су долазиле мисли да он то губи дугогодишњег пријатеља и сигурну подршку, и то у тренутку кад му она може да буде најпотребнија" (Андрић 1996: 383). Приказана ситуација показује и однос који се успоставио између Давила - конзула и Давила - обичног човека. Тај однос је свакако на штету овог другог.

Међутим, у роману „Травничка хроника” јавља се једна романескна ситуација, која представља изузетак када је реч о односу Давиловог јавног и приватног бића. Наиме, једном Давилово приватно биће реагује спонтано и без обазирања на Давилово јавно биће и на његов положај у датој ситуацији. Реч је о романескној ситуацији у којој Турци испред Аустријског генералног конзула, што ће рећи испред куће фон Митерера убијају осуђенике и њихове главе набијају на колац, те их тако остављају на том месту. Истовремено конзулати су удаљени јер се у том тренутку одвија рат између Француске и Аустрије. Међутим, искрено погођен ситуацијом у којој се нашао фон Митеpep, Давил реагује пре свега као приватно биће и аустријском конзулу шаље дирљиво, људско писмо у коме се налазе речи искреног саучешћа. Колико је та ситуација за Давила неуобичајена потврђује и нараторов коментар: „То је била једна од оних ситуација у животу када Давил јасно и право, без свог обичног колебања, зна шта треба радити и сме све и да уради” (Андрић 1994: 282). Овакво место нам сведочи да је Андрићев јунак сложен протагониста у чијем обликовању психолошка мотивација има значајну улогу. Давилова реакција дубоко је утемељена у психолошкој мотивацији, али и у филозофији егзистенцијализма, јер се француски конзул у деликатном положају показује као јунак који је ипак способан да се дефинише својим поступцима.

Дефосе, баш као и Давил, у себи носи исти сукоб приватног и јавног бића, само, с обзиром на његов карактер и с обзиром на његове мере вредности, тај сукоб је нешто мање изражен. Ипак, он не остаје непримећен, нарочито у оним ситуацијама какве прате и Давила, а реч је о ситуацијама када јунаци, ноћу, остају сами са собом и када, што је сасвим противно њиховом јавном држању, осете усамљеност и безнадежност сопственог положаја. И док Дефосе дању игра улогу младог канцелара и безбрижног, веселог и снажног младића, дотле ноћу осећа „како га ова земља и живот у њој нагризају, замарају и настоје да савију или сломе” (Андрић 1996: 81). 
У контексту принципа опозиције занимљиво је анализирати и поједине ситуације у којима се јунаци налазе, као и однос између тих ситуација. То нарочито има значаја за сагледавање Давиловог лика, где се могу довести у везу две ситуације у којима он у зависности од околности заузима потпуно супротне позиције, односно позиције које су антагонизми. Реч је о ситуацији када Давил сплеткама привремено зауставља долазак фон Митерера и ситуацији за коју се претпоставља да су се Турци послужили Давиловим именом да би домамили новског капетана у Травник. У првој ситуацији, Давил заправо заузима позицију каква се пре очекује код Турских протагониста. Коментаришући ситуацију у коју је Давил довео аустријског конзула још пре него што је фон Митерер стигао у Травник, приповедач нам експлицитно и каже да је оваква интрига карактеристична за Турке: „Тако се аустријском генералном конзулу десило оно што се готово редовно дешава странцима који долазе у Турску због неког посла са Турцима. Таквог човека Турци, нешто вољно и свесно а нешто и нехотице, самим стицајем околности, већ на првом кораку озлојаде, заморе и унизе, тако да странац приступа послу због кога је дошао већ са смањеном снагом и ослабљеним поуздањем у себе" (Андрић 1996: 91/92). Међутим, када се Турци послуже сличном сплетком, али која има бруталније последице, Давил јако добро осети супротну позицију од оне у којој се нашао када је ометао долазак и рад фон Митерера: „Давил је одболовао погибију новског капетана, а кад се дигао, рекао је сам себи: у зао час си дошао у ову земљу и сад одступања нема, али треба да имаш увек пред очима да поступке овога света не смеш мерити својом мером ни примити својом осетљивошћу, иначе ћеш у најкраће време бедно пропасти" (Андрић 1996: 203). Дакле, и Давил је на овом месту сасвим свестан положаја у коме се нашао и сукоба који се јавља између његовог приватног и јавног бића.

Андрић, мајстор приповедања, стварајући лик Давила, није пропустио да читаоцима покаже колико се тај јунак изменио током радње романа. Наиме, у двадесет и трећем поглављу романа, Андрић на сцени показује разлику између Давила када је дошао у Травник и Давила, који је као конзул већ провео одређени број година у Босни. По принципу два наспрамна огледала постављени су један наспрам другог Давил и Фресине, млади Француз, који у Сарајеву води француске трговинске послове. Фресине се Давилу жали, сав очајан, нашавши се у безнађу, на прилике које владају у Босни када је реч о француској трговини и уопштено када је реч о сарадњи странаца са домаћим светом. Слушајући га, Давил препознаје сопствене речи и сопствене тегобе, заправо Давил препознаје себе са почетка свог конзуловања, што експлицитно и коментарише: ,' 'Дакле тако сам ја изгледао у очима Дефосеа и свих оних којима сам толико пута говорио ово исто, истим тоном и начином', мислио је Давил у себи” (Андрић 1996: 359). Романескна ситуација о којој је реч веома је занимљива са становишта анализе Давиловог лика и са становишта анализе Андрићевог приповедачког поступка. Наиме, писац креира романескну ситуацију у коју, како би нагласио развој и промене у Давиловом лику, ставља лик конзула са почетка романескне радње наспрам лика француског конзула са краја радње романа. Давил сада сам себе у лику Фресинеа посма- 
тра са одређене временске дистанце, која подразумева конзулово сазревање у Босни. Давил сопствене тегобе и узнемирења слуша са дистанце која му омогућава и да их препозна и да их разуме, али и да утеши младог Фресинеа. До које мере се развио конзулов лик, и до које мере је улога конзула, дакле, јавног бића, постала доминантна у овог протагонисте снажно је наглашено управо у сусрету Давила и Фресинеа.

Давилов лик важна је тачка и за конструисање слике саме Француске као државе. Због тога изузетно значајно место представљају његова виђења и његови доживљаји Француске. Већ смо указали на то да се кроз овога јунака преламају колебања тадашње буржоазије између легитимног краља и Наполеона. Самим тим Давилов лик постаје део слике Француске за време Наполеона. Међутим, кроз његов лик, али и кроз коментаре наратора који се плету око његовог лика пред читаоце израста и слика Француске као земље, односно слика Француске која није условљена конкретним историјским околностима времена које се јавља у „Травничкој хроници”. С тим у вези нарочито је важно Давилово виђење Француске које се појављује у једном за јунака психолошки комплексном тренутку, а које до читаоца стиже посредством нараторовог коментара.

Наиме, везир с којим је Давил имао готово пријатељске односе и који је често ласкаво говорио о Француској одлази из Травника, чиме се Давилов осећај усамљености повећава. Након што се ван Травника растао са везиром, на повратку ка Травнику, дакле, на повратку у затворен простор у коме су сви сукоби везани за јунака лако видљиви, Давил размишља о Француској као о земљи спаса, али из позиције странца, а не из позиције некога ко је рођен у Француској, како нам то наглашава приповедачев коментар: „Чинило му се да схвата уопште како и зашто странци воле Француску, француски начин живота и француска схватања. Воле је по знаку противности; воле је, с правом, као слику свестране лепоте и складног, разумног живота, коју никаква тренутна замрачења не могу да измене и унаказе, и која се после сваке поплаве и сваког замрачења указује свету поново као неуништива снага и вечита радост; [...] Па, ево и он сам сада мисли о Француској, не као о својој родној земљи коју добро и одувек познаје и у којој је и зла и добра видео, него о Француској као дивној и далекој земљи склада и савршенства о којој се машта увек усред грубости и дивљине. Док је Европе биће и Француске и никад је не може нестати, осим да у извесном смислу (то јест у смислу светлог склада и савршенства) цела Европа постане једна Француска. Али то није могућно. Исувише су људи различити, туђи и далеки један другом" (Андрић 1996: 148)². Приповедачев коментар о коме је реч веома је значајан за слику Француске, која се на различите начине формира у роману. У њему

\footnotetext{
${ }^{2}$ Слику Француске која се јавља у наведеном цитату коментарисао је и Мидхад Шамић у својој чувеној студији „Историјски извори Травничке хронике Иве Андрића”, у којој он за овакво виђење Француске везује тренутак у коме Андрић пише свој роман и пишчево поромишљање значаја и позиције Француске у историји, као и положаја ове државе у Другом светском рату: „То мјесто, плод пишчеве инвенције, одликује се не само високим умјетничким квалитетима Андрићеве прозе, него и искреном пишчевом симпатијом према неким благородним цртама француског духа и цивилизације. [...] Не треба изгубити из вида да су ови редови написани за
} 
је наглашена врлина која се везује за Француску и наглашена је виталност врлине, што свакако представља редак омаж Француској, али и врлини као таквој.

Иако је овде Давилово виђење Француске преплетено са приповедачевим коментаром, у роману се на неколико места јавља Давилово позитивно виђење Француске, нарочито када је пореди са турским светом. Француска са њеним традиционалним вредностима за Давила представља место које је уточиште. С друге стране, када је слика Француске преломљена кроз сочиво једног поморског официра који казује Давилу да је цар луд и да са таквим вођом Француска иде путем велике несреће ${ }^{3}$ до читаоца стиже слика Француске маркирана конкретном историјском ситуацијом, а то су Наполеонови ратови.

Поред Давиловог сочива, Француска је приказана и посредством још неколико група, које у средишту свог виђења Француске имају пре свега Наполеона. Тако о цару говоре Французи, који су више забринути за своју будућност са вођом какав је Наполеон, потом католици, односно фратри који су због Наполеновог односа према цркви изразито негативни према Француској, и на крају Турци, чије мишљење о Наполеону и Француској зависи пре свега од њиховог положаја у коме се налазе у својој држави, односно у Отоманском царству. На крају, о Француској ће проговорити и Саломон Атијас: „У вашој земљи се дешавају мучне ствари и велике промене. Али ваша је земља племенита и моћна и све јој се мора на добро окренути" (Андрић 1996: 435). У средишту оваквог виђења Француске стоји иста идеја као и у Давиловом. Француска је и овде виђена као земља која традиционално има снажно укорењене врлине, које иако западају у различите врсте опасности што долазе са различитим друштвеним променама, не могу бити трајно угрожене.

На крају, када је реч о приказима Француске као државе, поред посредног начина у роману су присутни и веома ретки непосредни прикази Француске. Један од тих ретких приказа је и онај у којем се у кратким цртама описује конституисање Министарства спољних послова после Револуције: „Случај га је довео у Министарство иностраних послова у коме је тада било све поремећено и испретурано и у коме нико, од министра па до приправника, није био дипломата од заната, него су сви заједно учили из почетка ту вештину која је дотле била привилегија људи старог режима" (Андрић 1996: 60). Овде видимо Француску у контексту једне конкретне промене коју је, поред осталих, донела Револуција. Поред ове слике као непосредни прикази јављају се романескне ситуације везане за чиновништво Министарства спољних послова, који у грубим цртама конкретизују атмосферу Наполеонове Француске. Иако су непосредни прикази веома ретки, они су значајни јер

вријеме Другог свјетског рата, када је Француска доживљавала једно од својих 'замрачења' за владе маршала Петена и његових сарадника" (Шамић 2005: 122, 123).

${ }^{3}$ Овде ваља нагласити да то што је јунак под дејством алкохола не утиче на легитимност његових речи, јер их потврђује приповедачев коментар: „А трезни људи су другим речима шапутали исту мисао или су је крили у забринутом погледу” (Андрић 1996:63). 
употпуњују слику Француске која до читаоца долази првенствено преломљена кроз Давилово сочиво.

Принцип опозиције који је Андрић употребио на веома сложен начин у роману „Травничка хроника” омогућио је да се веома јасно виде карактери протагониста, али и природе ситуација у којима су се протагонисти нашли. Приказујући Француску у једном бурном, али за савремену државу, кључном историјском моменту, Андрић управо посредством контраста постиже да прикаже важан и комплексан период са свим својим сложеностима. Стављајући у центар свога романа лик француског конзула, који је истовремено носилац дилема француске буржоазије, Андрић гради слику Француске доминантно кроз лик Давила како се то може закључити на основу наше анализе. Тако формирана слика Француске чини се веома успела и жива. Она нам преноси не само дух једног времена него и живу слику једног света, којег је писац, како нам се чини, добро познавао.

\section{ЛИТЕРАТУРА}

Андрић 1996: И. Андрић, Травничка хроника, Београд: Просвета.

Кољевић 2015: С. Кољевић, Између завичаја и туђине, Нови Сад: САНУ огранак у Новом Саду; Академска књига.

Рудјаков 1998: П. Рудјаков, Историја као роман, Београд: Завод за уџбенике и наставна средства; Вукова задужбина / Нови Сад: Матица српска.

Џаџић 1993: П. Џаџић, Иво Андрић: човек, дело, Ниш: Просвета.

Шамић 2005: М. Шамић, Историјски извори Травничке хронике Иве Андрића, Београд: Гутембергова галаксија.

Штанцл 1987: Ф. К. Штанцл, Типичне форме романа, Нови Сад: Књижевна заједница Новог Сада.

Березовска 1986: V. Berezovska, Andrićevi konzuli na putevima Bosni, u: Život, mjesečni časopis za književnost i kulturu, god. 35, knj. 69, br. 5/6, maj-jun 1986, str. 530-540.

Јакобсен 2010: P. Jakobsen, Južnoslovenske teme, Beograd: SlovoSlavia.

Попадић 1980: Travnik i djelo Ive Andrića; zavičajno i univerzalno, ur. M. Popadić, Sarajevo: „Veselin Masleša”.

Фергусон 1978: A. Ferguson, Javni i privatni svetovi u ,,Travničkoj hronici”, u: Izraz: časopis za književnost i umetničku kritiku, god. 22, knj. 44, br. 6, jun 1978, str. 855-865.

Шамић 1954: M. Šamić, Neki momenti iz života i djelatnosti jednog francuskog konzula u Travniku početkom XIX vijeka, u: Pregled, god. 6, knj. 2, br. 9, septembar 1954, str. 129-135. 
Livija D. Ekmečić

\section{L'IMAGE DE LA FRANCE DANS „, LA CHRONIQUE DE TRAVNIK ”}

\section{(Résumé)}

Nous avons tenté dans ce travail, d'une part, de mettre en lumière l'mage de la France dans le roman „La Chronique de Travnik” et, d'autre part, d'analyser les personnages de Français et leurs relations réciproques. Nous montrons que l'image de la France se construit à deux niveaux. Le premier niveau est constitué par l'image de la France en tant qu'Etat, image qui est construite à la fois par des présentations directes mais également indirectes par le prisme d'un des personnages. Le second niveau est constitué par les protagonistes eux-mêmes, les Français. De même, nous mettons en exergue le principe de base par lequel Andric façonne l'image du monde français dans le roman , La Chronique de Travnik" : le principe de l'opposition ou plutôt du contraste. 